\title{
The Study of Local Wisdom of Ethnic Sasaks In Development of Biology Instructional Learning Program (P3Bio) Based on $21^{\text {st }}$ Century Skills
}

\author{
Septiana Dwi Utami, Ismail Efendi \\ Biology Education Study Program, IKIP Mataram \\ septianadwiutami@ikipmataram.ac.id, ismailefendibio@ikipmataram.ac.id
}

Ika Nurani Dewi

Science Education Study Program Post-Graduate School, Universitas Negeri Surabaya

iyan@is.its.ac.id

Agus Ramdani

Biology Education Study Program, Universitas Mataram

Aramdani07@unram.ac.id

Immy Suci Rohyani

Biology, FMIPA Universitas Mataram

immysuci@yahoo.co.id

\begin{abstract}
The Sasak community of Mount Rinjani region has been developed the original system of knowledge and technology as a local wisdom. Disclosure of local wisdom through biology instructional learning can strengthen the nature of meaningful learning and encourage students to be wise in solving the problems. A positive attitude is needed in this globalization era, in order to become a superior individual and dignity, but not exclude the local culture as a pillar of national identity. The purpose of this study is to describe the potential of local wisdom of Mount Rinjani area that can be used in the development of biology instructional learning program. This is a descriptive explorative research that uses ethnography method. The data are collected through several techniques: 1) interviews, 2) observation, and 3 ) literature review. The data are collected from various sources in the form of qualitative data, then analyzed descriptively the appropriateness of biological concepts and local wisdom that has been identified. The results show that the Sasak people of Mount Rinjani have developed the original system of knowledge and technology as a local wisdom in dealing with nature and the surrounding environment which is derived from religious values, customs, ancestors and local culture. Local knowledge, rules and customs of the communities in the Mount Rinjani region can be used as a learning source to develop the Biology instructional learning programs.
\end{abstract}

Keywords- Local Wisdom, Biology Instructional Learning Program.

\section{INTRODUCTION}

The following documents are some of the latest educational policies that should be anticipated by the Institute of Education and Education Personnel (IEEP). First, regulation of the Minister of Education and Culture of the Republic of Indonesia No. 65 of 2013 on learning processes in educational units states that it should be organized in an interactive, inspiring, fun, challenging, and also incite active participation of learners, and provide adequate space for initiative, creativity, and independence in accordance with talents, interests, and physical and psychological development of learners. For that cause, every educational unit must organize the learning plan, implementation and learning process to improve the efficiency and the effectiveness of gradúate competency standard [1]. Secondly, Presidential Regulation No. 8 of 2012 on Indonesian Qualification Framework (IQF) Chapter I, article 1.1 and article 1.2 states that IQF is a framework of competency qualification that can pair, equalize and integrate among the field of education, the field of job training, and working experience in order to provide job competence recognition in accordance with the structure of 1063 jobs in various sectors. Learning achievement is the ability gained through the internalization of knowledge, attitude, skills, competence, and accumulation of work experience [2]. Third, a 21st century skill is a set of abilities that must be possessed by learners to successfully live 
in the $21^{\text {st }}$ century. In that century, the world grows even more flat, and does not recognizing state borders anymore.

At that time, everyone should show independence, but also must be able to build cooperation and compete with others [3]. The essence of $21^{\text {st }}$ century skills is an emphasis on what students can do with knowledge, not on what unit of knowledge they have [4]. According to Duncan as quoted by [5], educators in the $21^{\text {st }}$ century must be given and prepared to utilize technological tools, should become collaborators in learning that constantly seek knowledge and acquire new skills with students. The $21^{\text {st }}$ century competency framework in improving the learning process to achieve life skills and career skills is as follows: 1) being flexible and adaptive, 2) taking initiative and independent, 3) possessing social and cultural skills, 4) being productive and accountable, 5) having a leadership skill and responsibilities. The above description of $21^{\text {st }}$ century learning requires a change of orientation in learning into mastering the combination of knowledge, skills, expertise, and proficiency. The $21^{\text {st }}$ century requires knowledge and understanding skills among all students. Students can think critically, solve problems, communicate effectively and collaborate with other students [6]. Kahl stated that the theme of $21^{\text {st }}$ century learning and innovation skills is creativity and innovation, critical thinking and problem solving, communication, and collaboration [7]. Additionally, the framework of Centre for Educational Research and Innovation (CERI) provides key competencies that affect the $21^{\text {st }}$ century job marketplace - skills in integrating interdisciplinary studies to understand global activities and regulations, and skills in creating the possibility of interacting with the global world [8].

One of the needs for global competence that suits the needs of $21^{\text {st }}$ century society is generic skills as a transferable competence which can be applied to various cross-disciplines of science. Thus, generic skills become a very important thing for students to be possessed because the skills are needed in order to be able to work in the community environment, continue the education degree, and develop a career.

Based on the empirical data above, the quality of the learning process should emphasize $21^{\text {st }}$ century skills so that the generic competencies of students can increase. In order to achieve the above objectives, a learning innovation with high academic legitimacy and relevance to the demands of society is required. One form of such innovation is to design a learning program aimed at providing students opportunities to expand and develop generic skills in the face of $21^{\text {st }}$ century challenges, without ignoring the local culture as a pillar of national identity. This $21^{\text {st }}$ century skills-based learning program becomes very urgent because through a series of learning activities that require thinking processes, it is believed to be an appropriate strategy to generate generic skills, and further to develop students' positive attitudes. Through this development research, it is expected that Biology learning process could improve and the generic skills of students could develop along with their positive attitude in order to be able to play an active role in the $21^{\text {st }}$ century

\section{METHOD}

This study is a product-oriented development study in education. The resulted product was developed using a development method that refers to the ADDIE development model [9]. Broadly speaking, the stages of the development model of ADDIE in the first year consists of (1) Analysis, (2) Design, and (3) Develop. In the analysis stage, the method used was ethnography aimed to describe and conduct an indepth analysis of the culture existing in the community [10]. Data collection was done through several techniques, namely, interview, observation, and literature review. Then, the data were analyzed using qualitative descriptive analysis.

\section{RESULTS AND DISCUSSION}

The findings in this study are presented in the form of 1) the types of local wisdom of Rinjani mountain community (Senaru Village, Sembalun Village, Aik Berik Village, and Lenek Duren Village), 2) the characteristics of the developed learning program. The results of the identification of local wisdom revealed in this study is descriptively presented in Table 1.

TABLE I. THE RESULTS OF THE IDENTIFICATION OF LOCAL WISDOM IN MOUNT RINJANI AREA

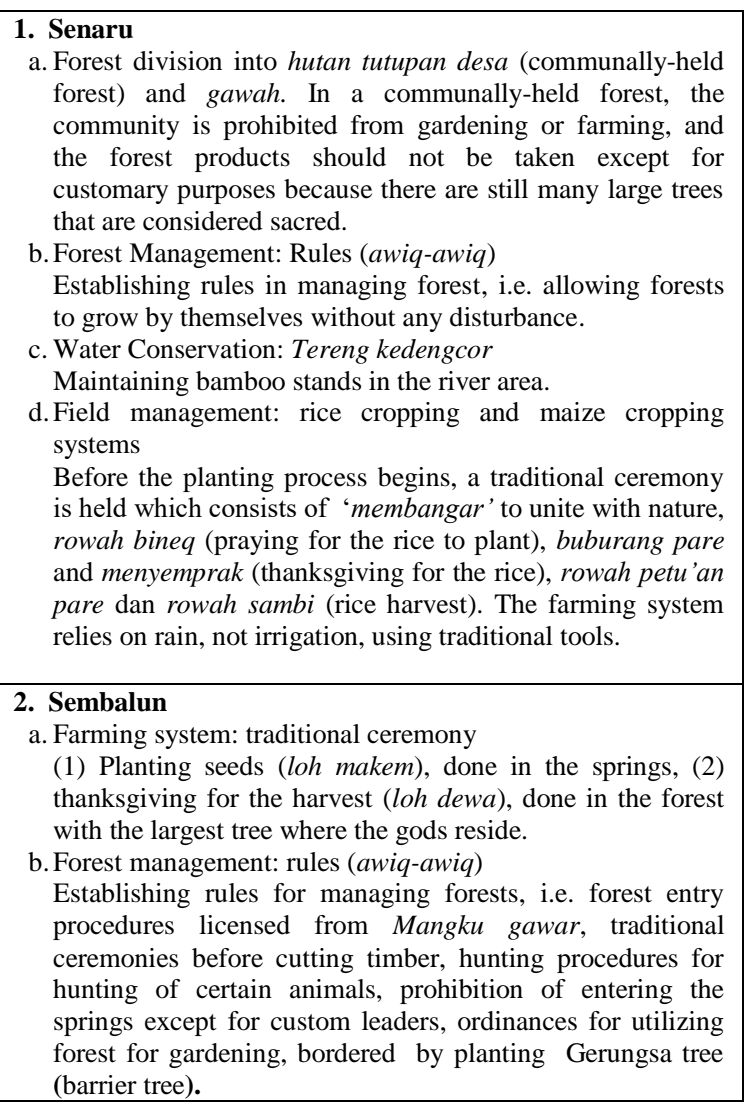

\section{Senaru}

Forest division into hutan tutupan desa (communally-held the forest products should not be taken except for customary purposes because there are still many large trees that are considered sacred.

Establishing rules in managing forest, i.e. allowing forests to grow by themselves without any disturbance.

d. Field management: rice cropping and maize cropping

is held which consists of 'membangar' to unite with nature, rowah bineq (praying for the rice to plant), buburang pare and menyemprak (thanksgiving for the rice), rowah petu'an pare dan rowah sambi (rice harvest). The farming system

Sembalun

(1) Planting seeds (loh makem), done in the springs, (2) thanksgiving for the harvest (loh dewa), done in the forest with the largest tree where the gods reside.

Establishing rules for managing forests, i.e. forest entry procedures licensed from Mangku gawar, traditional ceremonies before cutting timber, hunting procedures for certain animals, prohibition of entering the (barrier tree) 


\section{TABLE I. CONT.}

\begin{tabular}{l}
\hline c. Utilization of endemic plants: as medicinal plants \\
examples: centella (Cantella asiatica), prickly-leaved \\
elephants foot (Elephantus scaber), kencur (Kaempferia \\
galanga). \\
3. Aik Berik \\
The Sasak community in Aik Berik village views local \\
wisdom in the form of awiq-awiq which contains technical \\
rules for the implementation of community forestry \\
programs. The awiq-awiq content includes (1) the \\
necessity of planting trees on Community Forest \\
boundaries, (2) preserving and maintaining forest \\
sustainability, (3) regulating planting composition with a \\
ratio of 70\% of MPTS plants and 30\% timber, (4) \\
prohibition of abandonment of forest management \\
4. Lenek duren \\
The traditions or local wisdom in Lenek Duren village \\
are not written and its application is not like a community \\
that still holds the tradition. They understand awiq-awiq as \\
a good social habit to follow but not necessarily need to be \\
all implemented. Some forms of awiq-awiq that are still \\
applied are (1) the use of trees adapted to its nature, (2) \\
water use only for toilets and irrigation without polluting \\
water resources.
\end{tabular}

Based on the findings, the local wisdom of Sasak community at Rinjani mountain area that can be used as a source of learning consists of the knowledge of natural phenomena, knowledge of the physical environment, knowledge of the type of plants, benefits and cultivation. Such various local wisdom about environmental preservation is used as materials/media in Biology learning. Through integrated learning with local wisdom, it is expected to lead students to conduct direct observations in their neighborhood. Such activities can deepen the biological concepts that students have. The similar disclosure comes from John Dewey who states that students will learn well if what is learned related to what has been known regarding the events that occur around them $[11,12]$ state that real-world scenarios are an effective strategy for teaching science as a process.

In the development phase of the $21^{\text {st }}$ century skills-based, learning program begins with the analysis of students' initial knowledge. The next step is IQF curriculum analysis, and mapping of basic competencies. The results of the mapping are then organized into $21^{\text {st }}$ century skills-based learning programs. The results of the design of the learning program include 1) design, 2) implementation, and 3) evaluation. The developed learning program is supported by Ministerial Regulation of Education and Culture No. 65 of 2013 on process standards which states that to strengthen the scientific approach, it is necessary to apply a learning which refers to the process of inquiry. Looking at the potential of local wisdom in the $21^{\text {st }}$ century, integrating the value of local wisdom becomes important as one part of the nation's cultural wealth creation and filtration from outside cultural influences.
The developed Biology learning program is then operationalized into a learning program framework that includes (syllabus, semester learning plan, student worksheets, and assessment sheets). The developed program framework has the following characteristics: (a) emphasizing $21^{\text {st }}$ century skills mastery, (b) containing general information on practical activities for 1 semester; (c) adapted to process-based inquiry approaches; (d) used as a reference for developing learning devices.

\section{CONCLUSION}

The result shows that the local wisdom values in Sasak community of Mount Rinjani contain utilizing forest resources wisely, obeying all regulations (awig-awig) and community awareness related to forest conservation and protection of flora and fauna. The Biology learning program integrated with local wisdom is intended to retain local knowledge in the face of educational developments and advancements as well as increasing competitiveness in the $21^{\text {st }}$ century. Through integrated learning program of local wisdom, it is also expected to facilitate and prepare the students to become more competent and qualified human resources.

\section{References}

[1] Kemendiknas, Peraturan Menteri pendidikan dan Kebudayaan Republik Indonesia No 65 tahun 2013, Jakarta: Kementerian Pendidikan dan Kebudayaan, 2013.

[2] Deputi Bidang Kesejahteraan Rakyat, Peraturan Presiden Republik Indonesia Nomor 8 Tahun 2012 Tentang Kerangka Kualifikasi Nasional Indonesia, Jakarta: Deputi Bidang Kesejahteraan Rakyat, 2012.

[3] B. T. Binggeli, 21 St Century Chemestry, Florida: School Board Of Brevard Country, 2011.

[4] K. Sevilay, "Improving the Science Process Skill Ability of Science Student Teachers. Using I Diagram", Eurasian Journal Of Physics and Chemmistry Education, vol. 3, no. 1, pp. 26-38, 2008.

[5] R. W. Riley, "Educators, Technology and 21st Century Skills: Dispelling Five Myths A Study on the Connection Between K-12", Technology Use and 21st Century Skills, Walden University, pp 1-32, 2010 .

[6] Tucson, "The Partnership for 21st Century Skills has Developed a Vision for Student Success in The New Global Economy", www.21stcenturyskills.org 177, 2009.

[7] S. Kahl, "The Assessment of 21st Century Skills. Something Old, Something New, Something Borrowed", Paper presented at the National Conference on Student Assessment, Council of Chief State School Officers, Orlando, pp. 1-9, 2008.

[8] Centre for Educational Research and Innovation (CERI), Trends Shaping Education 2010, France: OECD, 2010.

[9] W. Dick, L. Carey, and J. O. Carey. J.O, The Systematic Design of Instruction, California: Addison Wesley Educational Publisher Inc, 2001.

[10] J. W. Creswell, Educational Reasearch, USA: Pearson, 2012.

[11] R. Moreno, Educational Psychology, New York: John Wiley and Sons, 2010.

[12] J. A. Morrison dan J. C. Estes, "Using Scientist and Real-World Scenario in Professional Development for Middle School Science Teacher", Journal of Science Teacher Education, vol. 18, no. 2, pp. 165 184, 2007. 